\title{
Synthesis, Crystal Structure and Biological Activity of Novel Diester Cyclophanes
}

\author{
Pengfei Zhang, Bingqin Yang,* Xianwen Fang, Zhao Cheng and Meipan Yang \\ Department of Chemistry, Key Laboratory of Synthetic and Natural Functional Molecule Chemistry, \\ Northwest University, Xi'an 710069, Shaanxi, P. R. China
}

\begin{abstract}
Uma série de novos ciclofanos diésteres foi sintetizada por esterificação de cloreto de 1,2 benzenodicarbonilo com oito diferentes dióis sob condições de elevada diluição. As estruturas dos compostos foram verificadas por análise elementar, ressonância magnética nuclear (NMR) de ${ }^{1} \mathrm{H}$, espectroscopia IR e espectrometria de massas de alta resolução (HRMS). As estruturas cristalinas de dois dos compostos foram caracterizadas por difratometria de raios X (XRD) de monocristais. Todos os novos ciclofanos foram avaliados com relação a suas atividades biológicas e os resultados mostraram que alguns destes compostos têm baixas atividades antibacterianas e antifúngicas.
\end{abstract}

A series of novel diester cyclophanes was synthesized by esterification of 1,2-benzenedicarbonyl chloride with eight different diols under high dilution conditions. The structures of the compounds were verified by elemental analysis, ${ }^{1} \mathrm{H}$ nuclear magnetic resonance (NMR), IR spectroscopy and high resolution mass spectrometry (HRMS). The crystal structures of two compounds were characterized by single crystal X-ray diffractometry (XRD). All the new cyclophanes were evaluated for biological activities and the results showed that some of these compounds have low antibacterial or antifungal activities.

Keywords: synthesis, ester cyclophanes, crystal, antibacterial activity, antifungal activity

\section{Introduction}

Cram and Steinberg ${ }^{1}$ opened the field of cyclophane chemistry by their work in 1951 . Since then, cyclophanes have attracted a great deal of attention from organic scientists, various kinds of compounds have been synthesized and their structures and properties have been studied..$^{2-6}$ Cyclophanes play an important role in host-guest chemistry because they can recognize specific molecules or ions by forming various inclusion complexes..$^{7-9} \mathrm{In}$ some reaction systems, the host-guest complex can simulate the high efficiency of enzyme catalysis, which means the reaction yield can be greatly improved. ${ }^{10,11}$ Besides, some ester cyclophanes were also used in the perfume industry because of their aromatic properties. Cyclophanes have so many important applications that it can be predicted a promising future in this field. However, the biological activities of cyclophanes were scarcely reported. ${ }^{12,13}$ Therefore, there is a continuous need to synthetize novel cyclophanes through efficient and simple routes and to study their biological activities.

*e-mail: yangbq@nwu.edu.cn
So far, scientists have synthesized a wide variety of cyclophanes with numerous modes of ring attachments. Medium-sized ring cyclophanes generally have a ring size of 8 to 11 atoms. ${ }^{14}$ Herein, it is reported the synthesis and biological activity of several diester cyclophanes. In continuation with our interest in cyclophane synthesis, ${ }^{15}$ an effective method for the synthesis of cyclophane compounds was designed, and a series of medium-sized cyclophanes $\mathbf{4 a - 4 h}$ was obtained by esterification of 1,2-benzenedicarbonyl chloride with some diols under high dilution conditions. Their antibacterial and antifungal activities are also described.

\section{Results and Discussion}

$O$-Phthalic acid undergoes a reaction with $\mathrm{SOCl}_{2}$ and catalytic DMF (dimethylformamide) to form the diacid chlorides $\mathbf{1}$ (Scheme 1). ${ }^{16}$ Diols 3a-3h were also prepared and used for the synthesis of cyclophanes. 4-Methylaniline was treated with oxirane and catalytic propanoic acid by stirring at room temperature for $24 \mathrm{~h}$. Diol 3a was obtained as white solid. ${ }^{17}$ Diols 3b, 3c, 3d, 3e and $\mathbf{3 f}$ were also prepared by similar procedures. Compounds $\mathbf{3 g}$ and $\mathbf{3 h}$ were obtained 
<smiles>CC(=O)c1ccccc1C(=O)O</smiles><smiles>O=S(=O)(O)O[Na]</smiles><smiles>O=C(Cl)c1ccccc1C(=O)Cl</smiles><smiles>Nc1ccccc1</smiles>

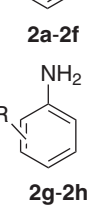<smiles>CCCC1OC1CCO</smiles>

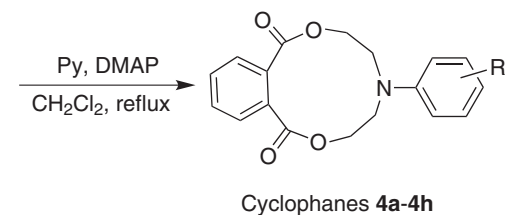

a: $\mathrm{R}=p-\mathrm{CH}_{3} \quad$ b: $\mathrm{R}=p-\mathrm{OCH}_{3} \quad$ c: $\mathrm{R}=p-\mathrm{Cl} \quad$ d: $\mathrm{R}=m-\mathrm{CH}_{3}$

$\begin{array}{lll}\text { e: } \mathrm{R}=m-\mathrm{Cl} & \text { f: } \mathrm{R}=3,5-\left(\mathrm{CH}_{3}\right)_{2} \quad \mathrm{~g}: \mathrm{R}=m-\mathrm{NO}_{2} \quad \text { h: } \mathrm{R}=p-\mathrm{Br}\end{array}$

Scheme 1. Synthesis of medium-sized cyclophanes $\mathbf{4 a - 4 h}$.

using $\mathrm{CaCO}_{3}, \mathrm{KI}$ and 2-chloroethanol according to Lin et al. ${ }^{18}$

Different catalysts showed different catalytic effect in the cyclization procedure. The inorganic base $\mathrm{K}_{2} \mathrm{CO}_{3}$ showed no catalytic activity. The reaction could be improved by adding pyridine, but the product yield was still low. It was found that a high cyclization yield was achieved in the presence of pyridine and 4-dimethylaminopyridine (DMAP). The reaction 1 equiv. of diol $3 \mathbf{a}$ with 1.5 equiv. of diacid chloride 1 in $\mathrm{CH}_{2} \mathrm{Cl}_{2}$ and in the presence of pyridine and DMAP afforded the cyclophane $4 \mathbf{a}$ in $56 \%$ yield. ${ }^{19-24}$ Using the new dual catalyst system not only increased the yield of the product, but also improved the reaction rate. The ${ }^{1} \mathrm{H}$ NMR spectrum of cyclophane $\mathbf{4 a}$ displayed the aromatic methyl protons as a singlet at $\delta 2.27, \mathrm{OCH}_{2} \mathrm{CH}_{2}$ protons as two triplet at $\delta 3.80$ and 4.55 with $J 4.0 \mathrm{~Hz}$, in addition to aromatic protons. Cyclophanes $4 \mathbf{b}-4 \mathbf{h}$ were also accessed by a familiar method from the reaction of diols $\mathbf{3 b} \mathbf{b} \mathbf{3 h}$ with diacid chloride 1. In order to avoid polymerization, the cyclization procedure was run under high dilution conditions and the reaction solution had to be vigorously stirred.

The carbonyl absorption of cyclophanes in the IR was in $1700-1720 \mathrm{~cm}^{-1}$ region, at lower frequency than that of normal esters due to the formation of a large $\pi$ bonding. This peak was the strongest peak compared with all other peaks in the IR spectrum.

\section{Crystal and molecular structures}

Crystals of compounds $\mathbf{4 g}$ and $\mathbf{4 h}$ were obtained from a mixture of petroleum ether and ethyl acetate (5:1). Crystal data collection and refinement parameters for the two compounds are shown in Table 1. The structures of compounds are presented in Figures 1a and 2a. The crystal structure X-ray analysis of $\mathbf{4 g}$ showed that there are six intermolecular $\mathrm{CH} \cdots \mathrm{OH}$-bonding interactions (Figure 1c): $\left[\mathrm{H}(2) \cdots \mathrm{O}(1)=2.697 \AA, \mathrm{C}(2)-\mathrm{H}(2) \cdots \mathrm{O}(1)=126.18^{\circ}\right]$;
$\left[\mathrm{H}(18) \cdots \mathrm{O}(4)=2.607 \AA, \mathrm{C}(18)-\mathrm{H}(18) \cdots \mathrm{O}(4)=153.84^{\circ}\right]$; $\left[\mathrm{H}(10 \mathrm{~B}) \cdots \mathrm{O}(4)=2.577 \AA, \mathrm{C}(10)-\mathrm{H}(10 \mathrm{~B}) \cdots \mathrm{O}(4)=135.39^{\circ}\right]$; $\left[\mathrm{H}(11 \mathrm{~A}) \cdots \mathrm{O}(6)=2.614 \AA, \mathrm{C}(11)-\mathrm{H}(11 \mathrm{~A}) \cdots \mathrm{O}(6)=143.53^{\circ}\right]$; $[\mathrm{H}(10 \mathrm{~A}) \cdots \mathrm{O}(5)=2.630 \AA, \mathrm{C}(10)-\mathrm{H}(10 \mathrm{~A}) \cdots \mathrm{O}(5)=$ $\left.163.21^{\circ}\right]$ and $[\mathrm{H}(9 \mathrm{~B}) \cdots \mathrm{O}(5)=2.552 \AA, \mathrm{C}(9)-\mathrm{H}(9 \mathrm{~B}) \cdots \mathrm{O}(5)=$ $159.46^{\circ}$ ]. The crystal structure $\mathrm{X}$-ray analysis of $4 \mathrm{~h}$ revealed cyclophanes connected by four intermolecular $\mathrm{CH} \cdots \mathrm{O}$ hydrogen bonding (Figure 2c): $[\mathrm{H}(3) \cdots \mathrm{O}(1)=2.410 \AA$, $\left.\mathrm{C}(3)-\mathrm{H}(3) \cdots \mathrm{O}(1)=153.69^{\circ}\right] ;[\mathrm{H}(7 \mathrm{~B}) \cdots \mathrm{O}(2)=2.699 \AA$, $\left.\mathrm{C}(7)-\mathrm{H}(7 \mathrm{~B}) \cdots \mathrm{O}(2)=158.01^{\circ}\right] ;[\mathrm{H}(17 \mathrm{~B}) \cdots \mathrm{O}(4)=2.587 \AA$, $\left.\mathrm{C}(17)-\mathrm{H}(17 \mathrm{~B}) \cdots \mathrm{O}(4)=133.99^{\circ}\right]$ and $[\mathrm{H}(18 \mathrm{~A}) \cdots \mathrm{O}(2)=$ $2.642 \AA, \mathrm{C}(18)-\mathrm{H}(18 \mathrm{~A}) \cdots \mathrm{O}(2)=164.49^{\circ}$ ]. The compounds were further stabilized by $\mathrm{H}$-bond stacking interaction to construct supramolecular architectures (Figures $1 b$ and $2 b$ ).

\section{Biological activity}

The synthesized novel compounds $\mathbf{4 a - 4 h}$ were screened for their in vitro antibacterial activity against Staphylococcus aureus (ATCC 25923), Bacillus subtilis (ATCC 6633), Escherichia coli (ATCC 25922), Pseudomonas aeruginosa (ATCC 27853) and Salmonella typhi (ATCC 14028). The new compounds $\mathbf{4 a}-\mathbf{4 h}$ were also evaluated for their antifungal activity against Candida albicans (ATCC 10231). The results of preliminary antibacterial activity of the compounds are shown in Table 2. A control test was performed with sterile DMSO. This revealed no inhibiting activity. The compounds $4 \mathbf{a}, \mathbf{4 b}, \mathbf{4 c}$ and $\mathbf{4 h}$ were found to exhibit higher antifungal activity against C. albicans among the new compounds.

The minimum inhibitory concentration (MIC) for the active compounds is presented in Table 3. Chloramphenicol and fluconazole were chosen as standard drugs whose MIC values are also provided in Table 3 . The antibacterial activity (MIC of $128 \mu \mathrm{g} \mathrm{mL}^{-1}$ ) of compound $\mathbf{4 g}$ against $E$. coli showed relatively better results than the other new compounds. This is 
Table 1 Crystallographic data and structure refinement parameters for the compounds $\mathbf{4 g}$ and $\mathbf{4 h}$

\begin{tabular}{|c|c|c|}
\hline Compound & $4 g$ & $4 h$ \\
\hline Empirical formula & $\mathrm{C}_{18} \mathrm{H}_{16} \mathrm{~N}_{2} \mathrm{O}_{6}$ & $\mathrm{C}_{18} \mathrm{H}_{16} \mathrm{BrNO}_{4}$ \\
\hline Color & yellow & white \\
\hline Formula weight & 356.33 & 390.23 \\
\hline Temperature / K & $296(2)$ & $296(2)$ \\
\hline Wavelength / & 0.71073 & 0.71073 \\
\hline Crystal system & monoclinic & monoclinic \\
\hline Space group & $\mathrm{P} 2(1) / \mathrm{n}$ & $\mathrm{P} 21 / \mathrm{c}$ \\
\hline Unit cell dimensions & $\begin{array}{c}a=7.925(2) \AA \\
b=15.854(4) \AA \\
c=13.208(3) \AA \\
\alpha=90^{\circ} \\
\beta=90.813(4)^{\circ} \\
\gamma=90^{\circ}\end{array}$ & $\begin{array}{c}a=21.197(4) \AA \\
b=4.8526(9) \AA \\
c=16.152(3) \AA \\
\alpha=90^{\circ} \\
\beta=99.692(3)^{\circ} \\
\gamma=90^{\circ}\end{array}$ \\
\hline Volume / $\AA^{3}$ & $1659.4(7)$ & $1637.7(5)$ \\
\hline $\mathrm{Z}$ & 4 & 4 \\
\hline Density / (mg m $\left.{ }^{-3}\right)$ & 1.426 & 1.583 \\
\hline Absorption coefficient / $\mathrm{mm}^{-1}$ & 0.109 & 2.532 \\
\hline$F(000)$ & 744 & 792 \\
\hline Crystal size / mm & $0.33 \times 0.27 \times 0.15$ & $0.33 \times 0.24 \times 0.15$ \\
\hline Range for data collection & $2.01^{\circ}$ to $25.10^{\circ}$ & $1.95^{\circ}$ to $25.10^{\circ}$ \\
\hline Limiting indices & $\begin{array}{c}-9 \leq h \leq 8 \\
-17 \leq k \leq 18 \\
-12 \leq l \leq 15\end{array}$ & $\begin{array}{c}-24 \leq h \leq 25 \\
-5 \leq k \leq 5 \\
-16 \leq l \leq 19\end{array}$ \\
\hline Reflections collected/unique & $6678 / 2930[R(\mathrm{int})=0.0329]$ & $7769 / 2897[R$ (int) $=0.0268]$ \\
\hline Completeness to theta $=25.10$ & $99.0 \%$ & $99.7 \%$ \\
\hline Refinement method & Full-matrix least-squares on $F^{2}$ & Full-matrix least-squares on $F^{2}$ \\
\hline Data/restraints/parameters & $2930 / 0 / 236$ & $2897 / 0 / 218$ \\
\hline Goodness-of-fit on $F^{2}$ & 1.026 & 1.039 \\
\hline Final $\mathrm{R}$ indices $[I>2$ sigma (I)] & $R 1=0.0494, w R 2=0.1158$ & $R 1=0.0318, w R 2=0.0674$ \\
\hline $\mathrm{R}$ indices (all data) & $R 1=0.0779, w R 2=0.1322$ & $R 1=0.0478, w R 2=0.0728$ \\
\hline Largest diffraction peak, hole / $\left(\mathrm{e} \AA^{-3}\right)$ & $0.191,-0.197$ & $0.275,-0.388$ \\
\hline
\end{tabular}

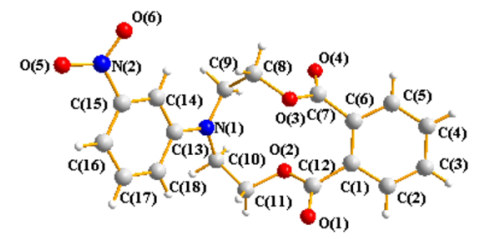

(a)

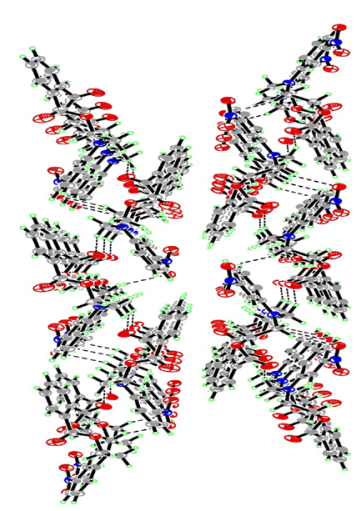

(b)

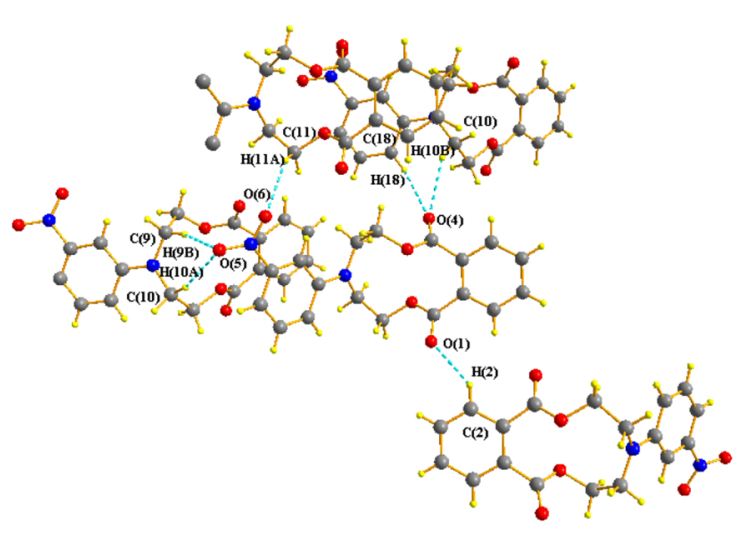

(c)

Figure 1. (a) Crystal structure of compound $\mathbf{4 g}$, (b) packing diagrams of $\mathbf{4 g}$ and (c) the arrangement of $\mathbf{4 g}$ showing the hydrogen bonding interactions.

attributed to the nitro unit substituent at the 4-position of the aryl ring. But the MIC value is relatively low for cyclophane $\mathbf{4 g}$ as compared with chloramphenicol. Compounds $\mathbf{4 a}$ and 4b had relatively higher activity against $C$. albicans (MIC of
$128 \mu \mathrm{g} \mathrm{mL}-1$ ) when compared with compounds $\mathbf{4 c}$ and $\mathbf{4 h}$. However, cyclophanes $\mathbf{4 a}$ and $\mathbf{4 b}$ were less effective than fluconazole. It is clear that all the synthesized cyclophanes have low antibacterial or antifungal activity. 


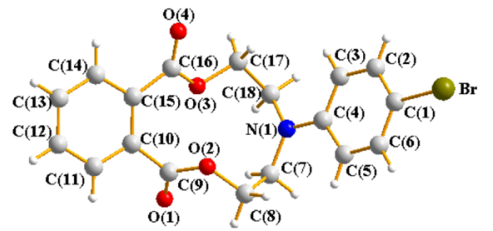

(a)

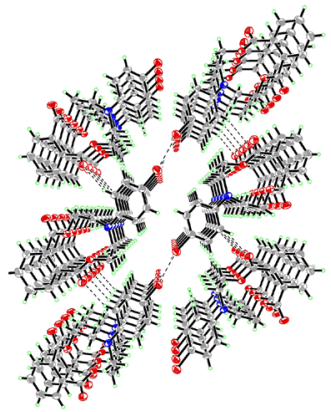

(b)

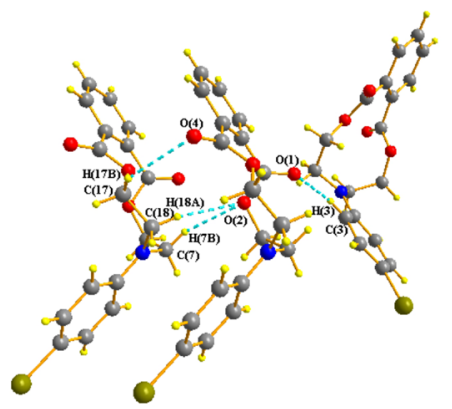

(c)

Figure 2. (a) Crystal structure X-ray analysis of $\mathbf{4 h}$, (b) packing diagrams of $\mathbf{4 h}$ and (c) the arrangement of $\mathbf{4 h}$ showing the hydrogen bonding interactions.

Table 2 Antimicrobial activity of the cyclophanes $\left(C_{\text {cyclophane }}=200 \mu \mathrm{g} \mathrm{mL} \mathrm{m}^{-1}\right)$

\begin{tabular}{|c|c|c|c|c|c|c|}
\hline \multirow{2}{*}{ Compound } & \multicolumn{5}{|c|}{ Bacteria } & \multirow{2}{*}{$\begin{array}{c}\text { Fungus } \\
\text { C. albicans }\end{array}$} \\
\hline & S. aureus & B. subtilis & E. coli & P. aeruginosa & S. typhi & \\
\hline $4 a$ & - & + & - & - & - & ++ \\
\hline $4 b$ & - & - & - & - & - & ++ \\
\hline $4 c$ & - & + & - & - & - & ++ \\
\hline $4 d$ & - & - & - & - & - & - \\
\hline $4 e$ & - & - & - & - & - & - \\
\hline $4 f$ & - & - & - & - & - & - \\
\hline $4 g$ & - & ++ & ++ & - & - & - \\
\hline $4 h$ & - & + & - & - & - & ++ \\
\hline Control & - & - & - & - & - & - \\
\hline
\end{tabular}

++: good inhibition; +: moderate inhibition; -: no inhibition.

Table 3. MIC values of antibacterial activity and antifungal activity $\left(\mu \mathrm{g} \mathrm{mL}{ }^{-1}\right)$

\begin{tabular}{lccc}
\hline Compound & B. subtilis & E. coli & C. albicans \\
\hline $\mathbf{4 a}$ & NA & NA & 128 \\
$\mathbf{4 b}$ & NA & NA & 128 \\
$\mathbf{4 c}$ & NA & NA & NA \\
$\mathbf{4 g}$ & NA & 128 & NA \\
$\mathbf{4 h}$ & NA & NA & NA \\
Chloramphenicol & 8 & 8 & - \\
Fluconazole & - & - & 16 \\
\hline
\end{tabular}

NA: not active $\left(>128 \mu \mathrm{g} \mathrm{mL}^{-1}\right)$.

\section{Experimental}

\section{Materials and equipment}

All reagents and solvents were purchased from Sinopharm Chemical Reagent Co., Ltd. The solvents were purified under conventional conditions or distilled immediately before use. The melting points were determined using an XT-4B micro-melting-point apparatus and are informed uncorrected. The elemental analyses for the compounds were carried out on a Vario EL III CHNOS instrument. The IR spectra $(\mathrm{KBr})$ were recorded on an Equinox-55 spectrophotometer. ${ }^{1} \mathrm{H}$ NMR spectra were recorded on an INOVA-400 NMR spectrometer, using TMS as internal standard and $\mathrm{CDCl}_{3}$ as the solvent. High resolution mass spectrometry (HRMS) were obtained with a MALDI-TOF mass spectrometer (Kratos Analytical Inc.). Column chromatography was performed on silica gel (200-300 mesh).

\section{Antibacterial and antifungal assays}

The bacteria and fungi were obtained from Shaanxi Province Institute of Microbiology (Xi'an, China) and maintained on Luria-Bertani (LB) medium consisting of the following: yeast extract $5.0 \mathrm{~g}$, peptone $10.0 \mathrm{~g}, \mathrm{NaCl} 10.0 \mathrm{~g}$, distilled $\mathrm{H}_{2} \mathrm{O} 1 \mathrm{~L}, \mathrm{pH} 7.5$ in slants or Petri plates at room temperature.

Preliminary antimicrobial activities of compounds $\mathbf{4 a - 4 h}$ were tested as follows: the new compound was dissolved in DMSO at the concentration of $200 \mu \mathrm{g} \mathrm{mL}^{-1}$ and placed on the LB plates that had been previously inoculated separately with the microorganisms. The plates were incubated at $35^{\circ} \mathrm{C}$, and the growth-inhibition zones were measured after $12 \mathrm{~h}$ in the case of bacteria/fungi.

The MIC values of the compound assays were carried out using the broth microdilution method. The tested compounds were dissolved in DMSO to afford $128 \mu \mathrm{g} \mathrm{mL} \mathrm{m}^{-1}$. Two fold 
dilutions of the solution were prepared $(64,32,16,8,4$, $2,1,0.5,0.25$ and $\left.0.125 \mu \mathrm{g} \mathrm{mL}^{-1}\right)$. The bacterial cultures

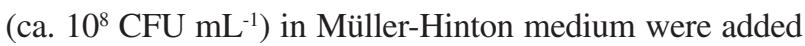
to the corresponding tubes. The plates were incubated at $35{ }^{\circ} \mathrm{C}$ for $12 \mathrm{~h}$. Chloramphenicol and fluconazole were used as reference agents. Suitable solvent control (DMSO), positive growth control and standard drug control were also run simultaneously. The MIC values of the compounds were recorded as the lowest concentration of each chemical compound in the tubes with no turbidity of inoculated bacteria/fungus.

\section{Crystal structure X-ray data of $\mathbf{4 g}$ and $\mathbf{4 h}$}

All measurements of compounds $\mathbf{4 g}$ and $\mathbf{4 h}$ were made on a Bruker Smart APEX II CCD diffractometer with graphite monochromated Mo- $\mathrm{K}_{\alpha}$ radiation. The data was collected at a temperature of $296 \mathrm{~K}$ using the $\omega$ - $2 \theta$ scan technique. Crystallographic data for the structure analysis of compounds $\mathbf{4 g}$ and $\mathbf{4 h}$ was deposited at the Cambridge Crystallographic Data Centre, CCDC No. 846714 and 846711, respectively. ${ }^{25}$

\section{Conclusions}

Eight novel compounds (4a-4h) were synthesized. XRD studies were carried out for compounds $\mathbf{4 g}$ and $\mathbf{4 h}$, which were further stabilized by $\mathrm{H}$-bond stacking interaction. These new compounds $\mathbf{4 a}-\mathbf{4} \mathbf{h}$ represent a novel class of compounds that incorporate an 11-membered ring lactone type structure. Some of the synthesized cyclophanes have low antibacterial or antifungal activities, providing stimulus for further studies.

\section{Supplementary Information}

Supplementary data is available free of charge at http://jbcs.sbq.org.br as PDF file.

\section{Acknowledgment}

This work was financially supported by the National Natural Science Foundation of China (Grant No. 21172178 P. R. China).

\section{References}

1. Cram, D. J.; Steinberg, H.; J. Am. Chem. Soc. 1951, 73, 5691.
2. Vögtle, F.; Cyclophan-Chemie; BG Teubner: Stuttgart, Germany, 1990.

3. Chen, P.; Jäkle F.; J. Am. Chem. Soc. 2011, 133, 20142.

4. Werz, D. B.; Fischer, F. R.; Kornmayer, S. C.; Rominger, F.; Gleiter, R.; J. Org. Chem. 2008, 73, 8021.

5. Jeppesen, J. O.; Nielsen, M. B.; Becher, J.; Chem. Rev. 2004, 104,5115 .

6. Srinivasan, M.; Sankararaman, S.; Hopf, H.; Dix, I; Jones, P. G.; J. Org. Chem. 2001, 66, 4299.

7. Rajakumar, P.; Padmanabhan, R.; Tetrahedron Lett. 2010, 51, 1059.

8. Arunachalam, M.; Ravikumar, I.; Ghosh, P.; J. Org. Chem. 2008, 73,9144 .

9. Bruno, G.; Cafeo, G.; Kohnke, F. H.; Nicolò, F.; Tetrahedron 2007, 63, 10003.

10. Morisaki, Y.; Ishida, T.; Chujo, Y.; Org. Lett. 2006, 8, 1029.

11. Morisaki, Y.; Chujo, Y.; Prog. Polym. Sci. 2008, 33, 346.

12. Rajakumar, P.; Abdul Rasheed, A. M.; Rabia, A. I.; Chamundeeswari, D.; Bioorg. Med. Chem. Lett. 2006, 16, 6019.

13. Melaiye, A.; Sun, Z.; Hindi, K.; Milsted, A.; Ely, D.; Reneker, D. H.; Tessier, C. A.; Youngs, W. J.; J. Am. Chem. Soc. 2005, $127,2285$.

14. Krafft, M. E.; Fu, Z.; Boñaga, L. V. R.; Tetrahedron Lett. 2001, 42, 1427.

15. Leng, X.; Yang, B.; Liu, Y.; Xie, Y.; Tong, J.; Z. Naturforsch., B: Chem. Sci. 2011, 66B, 930.

16. Guha, S.; Saha, S.; J. Am. Chem. Soc. 2010, 132, 17674.

17. Guo, C. C.; Li, K. L.; Tong, R. B.; Chen, L. Zhang, X. B.; Chin. J. Org. Chem. 2005, 25, 308.

18. Lin, S. W.; Sun, Q.; Ge, Z. M.; Wang, X.; Ye, J.; Li, R. T.; Bioorg. Med. Chem. Lett. 2011, 21, 940.

19. Lv, J.; Liu T. T.; Wang, Y. M.; Eur. J. Med. Chem. 2008, 43, 19.

20. Gao, M. Z.; Gao, G.; Xu, Z. L.; Zingaro, R. A.; Tetrahedron Lett. 2002, 43, 5001.

21. Gao, B.; Yang, B. Q.; Li, T.; Zhang B. L.; Synth. Commun. 2009, 39, 2973.

22. Abdel-Kader, M. S.; J. Braz. Chem. Soc. 2003, 14, 48.

23. Carrillo, R.; Martin, V. S.; López, M.; Martin, T.; Tetrahedron 2005, 61, 8177.

24. Cameron, L. M.; Fyles, T. M.; Hu, C. W.; J. Org. Chem. 2002, 67, 1548.

25. Cambridge Crystallographic Data Center (CCDC), 12 Union Road, Cambridge CB2 1EZ, UK, deposit@ccdc.cam.ac.uk, www.ccdc.cam.ac.uk/conts/retrieving.html accessed in August 2012 .

Submitted: July 11, 2012 Published online: September 25, 2012 